\title{
Universiteit
}

Leiden

The Netherlands

\section{Introduction to special issue: engaging christianities: negotiating HIV/AIDS, health, and social relations in east and southern Africa}

Prince, R.; Denis, P.; Dijk, R.A. van

\section{Citation}

Prince, R., Denis, P., \& Dijk, R. A. van. (2009). Introduction to special issue: engaging christianities: negotiating HIV/AIDS, health, and social relations in east and southern Africa. Africa Today, 56(1), v-xviii. Retrieved from https://hdl.handle.net/1887/14364

Version: $\quad$ Not Applicable (or Unknown)

License: $\quad$ Leiden University Non-exclusive license

Downloaded from: https://hdl.handle.net/1887/14364

Note: To cite this publication please use the final published version (if applicable). 


\section{Introduction to Special Issue: Engaging Christianities: Negotiating HIV/AIDS, Health, and Social Relations in East and Southern Africa}

Ruth Prince with Philippe Denis and Rijk van Dijk

The purpose of this special issue ${ }^{1}$ is to explore and analyze the ways in which Christianity is becoming one of the most influential factors in the engagement of AIDS in some African countries. This special issue addresses the consequences of this rapidly expanding Christian engagement with AIDS and the questions it raises. These questions can be grouped into three main themes: first, those concerning the ways people are dealing with illness and death, treatment and care for the sick, and questions of morality, kinship, gender relations, and sexuality; second, those concerning the place of religion in the public sphere, in relation to civil society and government, development, and public health; third, those concerning transformations within Christian practices and worldviews in Africa. This special issue explores not only some diverse responses of African churches to AIDS, but also the place of Christianity in (inter)national AIDS programs and initiatives, and the Christianization of public discourse and debate about AIDS and its effects on other institutions, practices, and debates in African societies experiencing the AIDS epidemic.

This special issue thus offers recent research and timely reflections on the interrelationships of Christianity, AIDS, and society in African countries. As the studies presented here encompass East and Southern Africa (specifically, Botswana, Kenya, Uganda, and Tanzania), this collection does not claim to present an overview of research in the whole continent, nor of the relations between Christianity and AIDS in Africa today; rather, it offers insights into the sometimes surprising relationships between AIDS and Christianity at particular moments and places over the last ten years. The topics covered here reflect current research trends: at our workshops on religion and AIDS, no one submitted a paper dealing with mainline churches, and there 
were few papers on African independent churches; in contrast, Pentecostal churches were a popular subject of research, as was the work of "faith-based organizations" in HIV/AIDS prevention and treatment projects and the growing public space occupied by Pentecostal morality that researchers observed in different African countries. It is hoped that a further publication on the topic will include a wider coverage of regions and churches.

The AIDS epidemic and its social, economic, and political ramifications have spawned much social and political-science, anthropological, and historical work (for an overview, see Becker \& Denis 2006). Religious engagements with AIDS have received less scholarly attention from social scientists and anthropologists. ${ }^{2}$ An exception is a recent special issue and an edited volume (Becker \& Geissler 2007a, 2009), which focus on the articulation of HIV/AIDS epidemic with religious practices and social relations in Africa (see also Becker 2008; Geissler \& Prince 2009). The papers, by anthropologists and one historian, are mostly based on research conducted before the advent of antiretroviral treatment (ART), in places where people were struggling with the epidemic and its effects. However, topics range from the understandings of HIV/AIDS and responses to the epidemic among Christian and Muslim communities to the articulation of HIV/AIDS programs, projects, and technologies_condoms, antiretrovirals, counselling techniques-with religious agendas and subjectivities. ${ }^{3}$

The current issue builds upon this work, but its focus is on Christian communities and the increasing prominence and weight of Christianity in responses to HIV/AIDS-in policies and programs, and at the grassroots, in daily life. Focusing particularly on the last decade, the papers in this volume explore the field of Christian-influenced engagements with HIV/ AIDS, paying attention to the debates, tensions, and negotiations it has opened up and the growing influence of Christian groups in AIDS-related interventions. The papers cover topics such as the increasing prominence of Christian discourses about kinship and culture in discussions about orphan care in Botswana (Dahl); Christian born-again rhetoric and generational politics among the "Joseph generation" in Uganda (Gusman); negotiations of care, belonging, and personhood in cases of sickness and death within a "faith church" in Botswana (Klaits); messages and activities in relation to HIV/AIDS in a Pentecostal church in Kenya (Parsitau); and a discussion of the field of religious engagements with HIV/AIDS in Tanzania, in relation to global funding of FBOs and the activities of Pentecostal churches (Dilger).

The papers included here draw on research conducted during the huge expansion of funds for HIV-AIDS programs that has occurred since 2002 and 2003, with the creation of the (international) Global Fund for HIV-AIDS, TB, and Malaria and the (U.S.) Presidential Emergency Fund for AIDS Relief (PEPFAR) (Dilger's and Klaits's papers also draw on fieldwork conducted before then). Dilger's paper deals directly with this global HIV/ AIDS industry, considering the convergence of religious agendas with development of the PEPFAR program between 2003 and 2008, as well as within some churches in Tanzania. Other authors (Parsitau, Gusman) consider the 
messages of particular churches about HIV/AIDS and how they articulate with HIV/AIDS education messages and efforts to deal with HIV/AIDS, driven by governments and nongovernmental organizations and influenced by foreign funding and development agencies. Three of the five papers focus on the convergence (Gusman, Parsitau) or divergence (Klaits) of various forms of Christianity with AIDS-education messages around morality, and their articulation with desires for a new "saved and safe" generation (Gusman). Several authors point to how Christian morality has become increasingly visible in the public sphere; Dahl's article, in particular, focuses on what she sees as an expanding discourse about Christian morality in relation to the care of orphans in Botswana.

The emergence of the AIDS epidemic in Africa has been accompanied by the growth of externally funded and managed projects aiming to disseminate knowledge, change practice, reduce stigma, provide care for HIV-positive persons, and support orphans and vulnerable children (OVCs). These projects have put new ideas of health, sexuality, gender relations and morality, human rights, and activism into circulation, and have drawn people into global currents and networks involving politics and development aid between north and south, which are in turn shaping the ways sickness and care are being negotiated and organized in African countries (e,g, Comaroff 2007; Iliffe 2006; Pfeiffer 2004). The rollout, since 2003 and 2004, of antiretroviral medicines in the countries covered by this issue, and the accompanying expansion of testing and treatment facilities have vastly increased the scale and "outreach" of AIDS programs (Nattrass 2005). Huge projects are now targeting HIV-positive people, providing HIV tests, counselling and treatment, and OVC support, while discourses about sexuality, responsibility for health, and human rights have assumed a new urgency (Fonchingong, Mbuagbo, \& Abong 2004; Nguyen 2004; Whyte et al. 2006; for outside Africa see Biehl 2004, 2006).

As the edited collections referred to above underline, religion has had an important role in framing people's understandings of and shaping responses to the AIDS epidemic (Becker \& Geissler 2007b, 2009); however, many religious institutions were, with exception, initially reluctant to engage directly with HIV/AIDS (Amanze 2000; Chitando 2007). It is important to note these exceptions: for example, the first home-based care projects in Zambia and Uganda were established by churches, mostly Methodist and Roman Catholic, by the late 1980s (Iliffe 2006); in western Kenya during the late 1990s, Roman Catholic NGOs were heavily involved in training home-based care workers and HIV/AIDS counselors, ${ }^{4}$ and in South Africa numerous church-based activities in the field of HIV/AIDS developed in the 1990s, many of them addressing the needs of orphans (Denis 2009). One of the first ARV rollout programs in South Africa was run by a Roman Catholic hospital near Durban (ibid.). Church involvement thus took different forms in different countries; but in general, the mainline churches-Anglican, Methodist, Roman Catholic-involved themselves in piecemeal responses to the pandemic during the 1990s, mostly involving home-based care, 
counselling work, and caring for orphans, and it was mainly the Pentecostal churches that refused to engage with HIV/AIDS until the year 2000 (see also Epstein 2007).

The reluctance of religious institutions to engage directly with HIV/ AIDS has changed in recent years, as religious groups including Pentecostal and mainline churches have become heavily involved in education, counselling, and care for AIDS patients (Burchardt 2009; Nguyen 2009), and even in AIDS treatment programs (Kalofonos 2008), as well as organizing care for orphans and vulnerable children. ${ }^{5}$ Development agencies (such as USAID), NGOs, and international organizations have begun to engage such institutions in development initiatives, AIDS projects, and treatment programs. The convergence between religion and development or humanitarian aid is captured in the notion of faith-based organizations (FBOs), introduced by the United Nations AIDS program and now circulating widely. ${ }^{6}$ Religious institutions are thus finding a place for themselves in the response to AIDS and the management of health and of new identities, communities, global networks, and futures (Adogame 2007; Cannell 2008; World Council of Churches 2005). The suffering wrought by HIV/AIDS has led the churches to revise their theology concerning the epidemic while their responses to HIV/AIDS have initiated a process of institutionalization, particularly among churches that were initially more centered on their leaders' charisma, such as Pentecostals. Within Christianity in Africa, these developments have often been interpreted as new challenges to the faith, leading to much debate within Christian circles and beyond about Christian theology, and about the relations between private and public domains of life and associated moralities (e.g. Richardson 2006). More broadly, these developments raise important questions about the place of religion in the public sphere, in relation to civil society and government, development activities, healthcare, and the AIDS epidemic. ${ }^{7}$

PEPFAR, which in 2003 earmarked 15 percent of its funds for abstinence-until-marriage HIV prevention programs, gave a huge boost to FBOs, as much of this funding was channelled to them. The religious, often Christian, agenda driving some African AIDS projects, programs, and policies receiving PEPFAR funds has received much scrutiny, both by journalists and within academia, while secular U.S. NGOs have voiced concerns about the blurring of boundaries between public health or development and Christian evangelism. ${ }^{8}$ Thus Helen Epstein $(2005,2007)$ draws attention to how Christian groups in the U.S., which had previously had little to do with HIV/AIDS prevention, care, or treatment, seized the opportunity presented by President Bush's initiative to evangelize as well as to fight HIV/AIDS; and she documents the colonization of AIDS policies in Uganda by projects promoting abstinence until marriage, driven by the dominance of born-again Christian agendas in both U.S. and Ugandan presidential politics (in 2003, President Museveni's wife lobbied President Bush to earmark funds for abstinence-only programs). This shift in AIDS funding had significant effects: in Uganda, earlier AIDS education campaigns based on a "zero-grazing" 
message ("reduce your number of sexual partners and use condoms") were replaced by abstinence-only campaigns; billboards advertising condoms were taken down in December 2004, and a condom shortage emerged. ${ }^{9}$ The Ugandan example illustrates the dovetailing of foreign and local born-again Christian agendas. In this special issue, Gusman's article suggests that faith-based responses to AIDS, such as Museveni's, reflect broader concerns held among Ugandans about the immorality of modern life, and the move in Ugandan society toward embracing born-again Christianity and its tenets of strict sexual morality and conservative family values. Such trends raise questions of how born-again agendas engage with other Christianities as they confront and aim to refashion moralities and relations. ${ }^{10}$

Three papers in this special issue deal with the engagements of churches and FBOs with HIV/AIDS, and consider their relation to PEPFAR funding and the shift toward abstinence-and-be-faithful messages; however, these observations emerge from particular times and places. PEPFAR is itself not monolithic, but encompasses many actors, political views, and institutions; moreover, it is not timeless. Contrary to Epstein's observations of PEPFAR-funded projects in their first years, American government staff administering PEPFAR funds and working on these issues on the ground are more flexible. We should not forget that PEPFAR is a government institution, answerable to Congress, which, since 2006 has had a Democratic majority. The initial influence of conservative values on PEPFAR has given way to a recognition that HIV/AIDS requires a multiplicity of approaches-a perspective that the Obama administration is likely to continue to pursue.

Whatever the short-term fluctuations in funding for FBOs, the move toward faith-based AIDS policies is contributing to the increased visibility of Christianity in the public sphere. This change is both quantitative and qualitative: while the involvement of religious institutions in welfare, education, and health services is not a new phenomenon in Africa, their numbers are increasing, as is the funding of their activities. The experience of HIV/AIDS is contributing to the popularity of Christian values in public life: values of love, brotherhood, equality, and honesty, which, while not specific to Christianity, seem to offer the possibility of rising above what African publics see as an increasingly immoral public sphere. In this context, politicians are encouraged to promote themselves as born-again Christians; Pentecostal preachers become popular political candidates (Parsitau 2008) while people in their daily lives prefer trusted church members and "strong Christians" in their economic dealings (Englund 2007). Such trends call for further analysis. To understand what is happening within Christianity in all its diversity in Africa, we should understand Christian responses to HIV/ AIDS: on the one hand, Christian debates about society and politics in the context of the HIV/AIDS epidemic, and on the other, church activities and ordinary Christian engagements with social and sexual relations, with illness, suffering, and death. Such analysis would go beyond assumptions about Christian fundamentalist agendas being transplanted with U.S. funds, to give a more nuanced understanding of African Christianity and African societies. 
Having said this, we should consider the consequences of the current prominence of Christian institutions in HIV/AIDS work and development more generally. Discussions of this topic tend to be colored by secular Western observers' deep dislike of fundamentalist forms of Christianity (particularly Charismatic Christianity and the Pentecostal churches popular among many Africans and many Americans) and their belief that religion is contradictory to development or modernization (Epstein 2007). The PEPFAR controversy forms only one facet of the interface between Christianity and AIDS; there is a broader trend toward recognition of the social work of faith-based groups and its actual and potential contribution to development (Belshaw, Calderisi, \& Sugden 2001; Hofer 2003; Shorter \& Onyancha 1998). Faith-based development, such as Roman Catholic hospitals and NGOs, has been effective, perhaps because, as Erica Bornstein points out (2007:665), it considers people's spiritual longings alongside their material needs. As Bornstein argues, we must understand why the Christian message of responding to spiritual and material needs, to morality as well as economic development, is so popular, and why the Christian ethos of brotherhood, love, equality, and honesty has so strong an appeal in situations where people feel there is a lack of trust and a moral corruption in public and private affairs (Englund 2007). Bornstein (2003) herself started out from a critical stance toward World Vision, an evangelizing FBO, as she followed its work in Zimbabwe. While she gained respect for its employees and their attempts to negotiate better lives and deal with poverty and social injustice, she also observes that World Vision's projects were a two-edged sword: while tackling poverty, they created new social inequalities and distinctions; their vision of economic development resembled neoliberal notions of individual responsibility and choice; and they effaced politics, reinforcing distinctions between givers and receivers of charity, offering no vision of political activism or transformation, while enabling the state to disengage further from its responsibilities.

The role of religion in development and the social work of religious institutions is hardly a new phenomenon in Africa, though the current degree of funding of FBOs is novel. Africa has a long-standing tradition of Christian philanthropy and evangelizing through schools, hospital, and dispensaries (Sabar-Friedman 1996). In colonial times, the authorities were by and large content to leave the health of colonial populations in the hands of the missions (Beck 1970; Ranger 1992). The first hospitals in Africa were mission hospitals, just as most of the first schools were mission schools. This changed with independence. Scores of mission hospitals were nationalized. What we see today is a return to nongovernmental and faith-based healthcare, not through mission hospitals, but through FBOs and NGOs.

While there is a large body of work on colonial-era Christian missions and Christian religious movements and the shaping of subjectivities and social relations, there are few in-depth studies of contemporary relations between religion and development that analyze effects on local societies, Christianity, and broader structures of governance in health, education, and development (Bornstein's study is an exception). Similarly, while 
development studies is a thriving discipline, the place of religion in development has received less attention (but see Ter Haar and Ellis 2006). The topic deserves analysis, for two main reasons: first because, as Bornstein points out (2007:659), a particular vision of progress accompanies this trend toward faith-based humanitarianism; second, because it forms part of a broader trend toward "nongovernmental government" or "nongovernmental politics" (Feher 2007; Fisher 1997). Rooted in Euro-American Christian notions of choice and individuality, this vision of progress resonates with the neoliberal project that, since the 1980s in Africa, has moved to pare back the state and promote civil society as its counterpoint, delegating responsibility to NGOs and FBOs, with the effect, critics argue, of placing responsibility for survival on the individual and on institutions that are not accountable to the citizens of the country. The humanitarian model of development-championing charity and based on a Christian notion of giving, rather than on welfare and its associated rights and claims-has long-term consequences for visions of politics and the relations between governments and their citizens (Feher 2007; see also Harper \& Maddox 2009).

Such reflections on "nongovernmental government" raise further questions concerning the role of religious institutions and FBOs in shaping this field. First, to what extent do church communities, such as the Pentecostals described here, reflect, but also counter, the tendency of NGOs and FBOs to constitute their objects as needy individuals and populations? Do church communities create reciprocal relations and build up communities of care that counter neoliberal models of charity? (See the articles by Dilger and Klaits). Many churches-in particular non-mainline churches, such as Pentecostals-rely on the contributions of their congregations for their maintenance and activities; many are proud of this self-reliance, and some counterpose this to the scramble among NGOs and FBOs to access donor funds. At the same time, churches, and again particularly Pentecostals, preach a Christianity based on individualism, choice, and empowerment, of becoming "born again," and in so doing making a choice of placing believers' lives in their deity's hands. Does this place responsibility for success or failure on the individual? or does it place the individual within God's hands and God's plans? There is much variation here, but one answer can be found in the distinction Pentecostals make between saved and non-saved: as Gusman's article shows, the new generation of youth places responsibility for the AIDS epidemic squarely on the previous generation, portrayed as being morally inferior; however, as Klaits's article shows, other Christian churches strive to avoid apportioning blame, regarding this as challenging their notions of Christian love, the relationship with God, and the relations upon which their Christian community is built.

A second question concerns the effects that delegating responsibility for social services-whether health and HIV/AIDS, or education or social welfare-to churches, FBOs, and NGOs has. Who has ultimate responsibility in this transnational and decentered sphere of development? FBOs and NGOs usually run projects based on limited periods, because of the nature 
of the funding they receive; a change of policy at headquarters affects activities elsewhere. ${ }^{11}$ How accountable are these institutions-churches, as well as NGOs and FBOs-to the communities they target and serve? Is the current involvement of these institutions in HIV/AIDS work temporary, a transitional state in the development of African states? Or do the activities of these institutions indicate, as all the evidence suggests, a further stage in the disintegration of government and fragmentation of services among institutions unaccountable to the people they serve?

Leaving aside the question of religion and development and turning toward Christianities themselves, we should note that one of the ways in which HIV/AIDS transformed the churches was by forcing them to reconsider their theology. Initially, many church leaders presented HIV/AIDS as a punishment from God, hence as a misfortune affecting sinners. This view was shared by mainline churches, African independent churches, and Pentecostals. When the churches began to face the fact that that many of their members and sometimes some church leaders themselves were infected, they revised their judgmental attitudes and acknowledged that they had indeed contributed to stigmatization of HIV positive people. This theological revision took time, and there was a long period of silence and denial among church leaders, as some have since admitted. ${ }^{12}$ Again, the responses of the churches were varied. African mainline churches took up the challenge earlier, while, as some of the contributions to this special issue point out, Pentecostal churches began to revise their theology concerning HIV/AIDS only from about 2001. HIV/AIDS also forced the churches to discuss issues that were not on the agenda before (Dube 2003; Nicolson 1996). In this way, sexuality came out of the closet. ${ }^{13}$ The fact that many faithful wives became infected because their husbands had another view of marriage suddenly became visible. In many churches in Africa, gender issues are now discussed, and discussed more openly than ever before, and this is because of HIV/AIDS (Phiri et al. 2003). The body—we should say, the sick body—has become a theological theme. For the African mainline churches, healing was a peripheral issue; with the advent of HIV/AIDS it has gained prominence. ${ }^{14}$

The shift in theology in relation to HIV/AIDS among Pentecostal churches in East Africa is examined in the contributions by Parsitau and Gusman, who argue that it parallels a move from an "otherworldly" to a "this-worldy" attitude, and an increasing engagement in social issues affecting church communities. HIV/AIDS, the body, sexuality, and illness have become the focus of church sermons, as well as church teachings and activities targeting in particular young unmarried people. Both papers document how public these issues have become within these churches and how they try to make their messages attractive to youth, but at the same time they show that, by moralizing sexuality, gender relations, and the body in general, the churches contribute to the stigmatization of HIV/AIDS, and that, by reducing issues of sexuality and morality to personal choice and self-determining agency alone, they obscure the importance of material conditions that shape sexual relations and underlie the spread of the virus, 
such as poverty and social inequality. Rather than initiating dialogue, the moralizing messages of these churches produce in many young people a feeling of failure (Smith 2004). Pope Benedict XVI's recent statement on the ill effects of condom-based AIDs prevention campaigns is another example of the potentially harmful effect of Christian moral messages.

Fred Klaits's paper grapples with the broader implications of such messages about sexuality and shows how they often sit at odds with concerns about caregiving relationships which people are confronted with in the context of HIV/AIDS. Drawing upon his ethnography of an independent Apostolic "church of the spirit" in Botswana, he shows how both moral issues at stake in HIV/AIDS prevention campaigns and the church's ideas about Christian love and care shape the way people talk—or don't talk-about HIV/ AIDS and sexuality. He highlights how assumptions that are often implicit in HIV/AIDS campaigns about people's ability to choose lifestyles have the effect of positioning the "saved" and the "nonsaved," the healthy and the sick, in a moral gridlock (see also Geissler \& Prince 2007). Talking about HIV/AIDS thus forces people to take sides and make moral judgments, which may sit at odds with other issues at stake in relation to HIV/AIDS, such as the quality of caregiving and love among church members.

The papers point to the importance of Christian values, morals, and practices in the ways both people and institutions in many African countries are dealing with AIDS, and explore the disciplining and the liberating potential of Christianity in these contexts, as well as the tensions it engenders. The papers address questions of whether AIDS has opened up an opportunity for the spread of Christian values and worldviews; whether the experience of the AIDS epidemic has encouraged a deeper involvement with Christianity and with particular Christian churches; and whether Christian engagements with AIDS are themselves expanding Christian influence, shaping moralities and perspectives beyond Christian institutions and congregations. The papers point to how the AIDS epidemic has precipitated an evaluation of moralities and practices concerning bodily health and illness, sexuality, kinship and gender relations, care, and death-an evaluation driven by local moral and religious concerns and linked to international and national AIDS intervention policies and programs, which may target what are perceived to be particular local or cultural practices.

The papers explore diverse Christian understandings of subjectivity, social relations, and moral community, as well as ideas and practices about health and illness, sexuality, treatment and care, and death. Christian influence on moral and material practices, on body and relations, is of specific significance for understanding the engagement with AIDS (Henderson 2004). Fred Klaits's paper most directly engages with this subject, but all the papers here, in different ways, deal with responses to suffering and relations of care, from family to church to orphanage and community-based organization. Subjects that are not dealt with directly in the present issue are those of healing (though earlier work of Dilger and Klaits on care and community explore this issue in more detail [Dilger 2007; Klaits 2005, 2009; see also van 
Dijk 2006] and treatment with antiretrovirals. It is hoped that this special issue will stimulate further publications and research on the interrelations between Christianity and AIDS in the areas of FBOs' involvement in AIDStreatment programs and counselling, and in Christian churches' attempts to heal through spiritual as well as material means. ${ }^{15}$

\section{NOTES}

This special issue is based on two workshops organized by the Research Network on Religion and AIDS in Africa, held in Leiden (2007) and Copenhagen (2008). The editors would like to thank Niels Kastfelt, Susan Whyte, Michael Whyte and Catrine Christiansen for their support for the workshops. For support in the writing of this introduction Ruth Prince would like to thank the Centre of African Studies, University of Cambridge and the Institute of Social Anthropology, University of Oslo.

1. A further workshop was held at Justo Mwale College, Lusaka, Zambia, from 15 to 18 April 2009, titled Prolonging Life, Challenging Religion: ARVs, New Moralities and the Politics of Social Justice.

2. Theologians and religious scholars in Africa have been more active in this field. See, for example, the project "Collaborative for HIV and AIDS, Religion and Theology" (CHART), a project of the School of Religion and Theology, University of KwaZulu-Natal. The bibliography compiled by CHART gives a picture of the vitality of research on HIV/AIDS theology (www .chart.ukzn.ac.za).

3. E.g., Becker 2007; Beckmann 2009; Behrend 2007; Burchardt 2009; Christiansen 2009; Dilger 2007; Niehaus 2009; Nguyen 2009; Prince 2007; Sadgrove 2009; Svensson 2009; van Dijk 2009.

4. Interviews with the program coordinator of a local Roman Catholic NGO in Kisumu, Kenya, March 2009, Ruth Prince.

5. For example, the Deliverance Church in Kenya has set up an FBO that manages a sponsorship program involving foreigners' payments for the school fees of orphaned children, while international FBOs such as World Vision channels its sponsor-an-orphan program through local Kenyan FBOs, which employ volunteers who locate needy children and monitor the transferral of funds and the children's progress.

6. Religious institutions debate the use of the term $F B O$, as it does not differentiate among churches, dioceses, parishes or congregations that are involved in the fight against HIV/AIDS and faith-based organizations focusing specifically on HIV/AIDS.

7. For recent discussions of Christianity and the public sphere in Africa, see Englund, forthcoming; Meyer \& Annelies 2006; see also Gifford 1995, 1998; Maxwell 2000.

8. "US Congress introduces new PEPFAR bill: two steps forward, three steps back," press release of the Centre for Health and Gender Equity, 27 February 2008 (www.pepfarwatch.org); "George Bush: a good man in Africa" by Chris McGreal in The Guardian, 15 February 2008 (www.guardian.co.uk/world/2008/feb/15/georgebush, accessed 19 February 2008); "USAID contracts with faith-based organizations," The Boston Globe survey, and "Bush brings faith to foreign aid," The Boston Globe, 8 October 2006 ( (www.boston.com/news/nation/articles/2006/10/08/bush, retrieved in February 2008). "Panel approves global AIDS spending hike," by the Associated Press, The New York Times, 27 February 2008 (www.nytimes.com/aponline/us/AP-Global-AIDS .html, retrieved in February 2008). 
9. Citing research by Human Rights Watch, Epstein argues that abstinence-based programs in the U.S. have largely failed to reduce rates of teen pregnancy or sexually transmitted diseases, and that claims that Uganda's reduced HIV rates are based on higher abstinence rather than increased use of condoms are unfounded; however, other observers argue that increased abstinence and faithfulness among Ugandans in response to HIV-AIDS education and the wave of born-again Christianity have contributed substantially to the reduction of HIV infection rates (Green 2003).

10. See Geissler \& Prince 2009; Prince 2007 for a discussion of these issues.

11. As Prince observed in Kenya, where one U.K.-based NGO, which had initiated a program of school fees and food baskets suddenly lost its funding, while another changed its priorities, leaving the children and their families, who had been promised that they would be supported through school, in the lurch.

12. For example, in 2006, Kenya's Anglican Archbishop Benjamin Nzimbi apologized to HIVpositive people on behalf of the church for comparing the disease to a "curse from God," as reported in the Kenyan Daily Nation ("Kenyan Anglican Church Official Apologizes for Likening HIV/AIDS to 'Curse From God,' 17 March 2006, http://www.kaisernetwork.org/daily_reports/ rep_index.cfm?hint=1\&DR_ID=36078, retrieved 14 July 2009).

13. The phrase is from Paterson 2008.

14. Denis 2008, a revised version of a paper read at the Copenhagen workshop in April 2008.

15. See also Luedke 2007 and other articles in the 2007 special issue of the Journal of Southern African Studies, on "Histories of Healing" (Schumaker, Jeater, \& Luedke 2007).

\section{REFERENCES CITED}

Adogame, Afe. 2007. HIV/AIDS Support and African Pentecostalism. Journal of Health Psychology 12(3):475-487.

Amanze, J. N. 2000. Covenant with Death: the Attitude of Churches in Botswana towards the Use of Condoms by Christians, and its Social Implications. Botswana Notes and Records 32:201-208.

Beck, Ann. 1970. A History of the British Medical Administration of East Africa 1900-1950. Cambridge, Mass.: Harvard University Press.

Becker, Charles, and Philippe Denis. 2004. L'épidémie du sida en Afrique subsaharienne: Regards historiens. Paris: Karthala.

Becker, Felicitas. 2007. The Virus and the Scriptures: Muslims and AIDS in Tanzania. Journal of Reliqion in Africa 37(1):16-40.

Becker, Felicitas. 2008. Becoming Muslim in Mainland Tanzania. Oxford and London: Oxford University Press and the British Academy.

Becker, Felicitas, and P. Wenzel Geissler. 2007a. Faith and AIDS in East Africa. Special issue. Journal of Religion in Africa 37(1):1-149.

Becker, Felicitas, and P. Wenzel Geissler. 2007b. Searching for Pathways in a Landscape of Death: Religion and AIDS in East Africa. Introduction to the special issue. Journal of Religion in Africa 37(1):1-15.

Becker, Felicitas, and P. Wenzel Geissler, eds. 2009. Aids and Religious Practice in Africa. Leiden, Boston: Brill 
Beckmann, Nadine. 2009. AIDS and the Power of God: Narratives of Decline and Coping Strategies in Zanzibar. In Aids and Religious Practice in Africa, edited by Felicitas Becker and P. Wenzel Geissler. Leiden, Boston: Brill.

Behrend, Heike. 2007. The Rise of Occult Powers, AIDS, and the Roman Catholic Church in Western Uganda. Journal of Religion in Africa 37(1):41-58.

Belshaw, D. G. R., R. Calderisi, and C. Sugden, eds. 2001. Faith in Development: Partnership between the World Bank and the Churches of Africa. Washington, D.C.: World Bank.

Biehl, Joao. 2004. The Activist State. Global Pharmaceuticals, AIDS and Citizenship in Brazil. Social Text 22(3):105-132.

2006. Will to Live: AIDS Drugs and Local Economies of Salvation. Public Culture 18(3):457-472.

Bornstein, Erica 2003. The Spirit of Development: Protestant NGOs, Morality and Economy in Zimbabwe. London: Routledge.

-2007. Faith, Liberty and the Individual in Humanitarian Assistance. In Nongovernmental Politics, edited by M. Feher with G. Krikorian and Y. McKee. New York: Zone Books.

Burchardt, Marian. 2009. Subjects of Counselling: Religion, HIV/AIDS and the Management of Everyday Life in South Africa. In Aids and Religious Practice in Africa, edited by Felicitas Becker and P. Wenzel Geissler. Leiden, Boston: Brill.

Cannell, Thomas. 2008. African Churches and AIDS Prevention: Much Still to be Learned. Retrieved 18 July 2008 from http://forums.csis.org/africa/?p=113.

Chitando, Ezra. 2007. Living with Hope: African Churches and HIV/AIDS 1. Geneva: World Council of Churches Publications.

Christiansen, Catrine. 2009. The New Wives of Christ: Paradoxes and Potentials in the Making of Widows' Lives in Uganda. In Aids and Religious Practice in Africa, edited by Felicitas Becker and P. Wenzel Geissler. Leiden, Boston: Brill.

Comaroff, Jean 2007. Beyond Bare Life: AIDS, (Bio)Politics, and the Neoliberal Order. Public Culture 19(1):197-219.

Denis, Philippe. 2008. AIDS and Religion in Sub-Saharan Africa in a Historical Perspective. Paper read at the workshop organized by the Collaboration on HIV and AIDS, Religion and Theology (CHART), University of KwaZulu-Natal, in Durban, 12-17 October.

—. 2009. The Church's Impact on HIV/AIDS Prevention and Mitigation in South Africa. Journal of Theology for Southern Africa 134:66-81.

Dijk, Rijk van. 2006. Transnational Images of Pentecostal Healing: Comparative Examples from Malawi and Botswana. In Borders and Healers. Brokering Therapeutic Resources in Southeast Africa, edited by Tracey J. Luedke and Harry West. Bloomington: Indiana University Press.

Dijk, Rijk van. 2009. Gloves in Times of AIDS: Pentecostalim, Hair and Social Distancing in Botswana. In Aids and Religious Practice in Africa, edited by Felicitas Becker and P. Wenzel Geissler. Leiden, Boston: Brill.

Dilger, H. 2007. Healing the Wounds of Modernity: Salvation, Community and Care in a NeoPenteocostal Church in Dar-es-Salam, Tanzania. Journal of Religion in Africa 37(1):59-83.

Dube, Musa. 2003. Methods of Integrating HIV/AIDS in Theological Programmes. Geneva: World Council of Churches.

Englund, Harri. 2007. Pentecostalism beyond Belief: Trust and Democracy in a Malawian Township. Africa 77(4):477-499.

ed. Forthcoming. Public Culture and Christianity. Athens, Ohio: Ohio University Press.

Epstein, Helen. 2005. God and the Fight Against AIDS. The New York Review of Books 52:7. 
2007. The Invisible Cure: Africa, the West and the Fight Against AIDS. New York: Farrar, Straus and Giroux.

Feher, M., G. Krikorian, and Y. McKee, eds. 2007. Nongovernmental Politics. New York: Zone Books.

Fisher, W. 1997. Doing Good? The Politics and Antipolitics of NGOs' Practices. Annual Review of Anthropology 26:439-464.

Fonchingong, C. C., O. T. Mbuagbo, and J. T. Abong. 2004. Barriers to Counselling Support for HIV/AIDS Patients in South-Western Cameroon. African Journal of AIDS Research 3(2):157-165.

Geissler, P. Wenzel, and Ruth J. Prince. 2007. Christianity, Tradition, AIDS and pornography: Knowing sex in western Kenya. In: On Knowing and Not Knowing in Anthropology, edited by Roland Littlewood: London: UCL Press.

Geissler, P. Wenzel, and Ruth J. Prince. 2009. In press. The Land is Dying: Contingency, Creativity and Conflict in Kenya. Oxford: Berghahn Press.

Gifford, Paul. 1995. The Christian Churches and the Democratisation of Africa. New York: E. J. Brill.

—. 1998. African Christianity: Its Public Role. Bloomington: Indiana University Press.

Green, Edward C. 2003. Faith-Based Organizations: Contributions to HIV Prevention. USAID Report, September.

Harper, lan, and Bryan Maddox. 2009. The Impossibility of Well-Being: Development Language and the Pathologisation of Nepal. In Culture and Well-Being: Anthropological Approaches to Freedom and Political Ethics, edited by Alberto Corsin-Jimenez. New York: Palgrave Macmillian.

Henderson, P. C. 2004. The Vertiginous Body and Social Metamorphosis in a Context of HIV/AIDS. Anthropology Southern Africa 27(1/2):43-53.

Hofer, K. 2003. The Role of Evangelical NGOs in International Development: A Comparative Case Study of Kenya and Uganda. Afrika Spectrum 38(3):375-398.

Iliffe, John. 2006. The African AIDS Epidemic: A History. Oxford, James Currey.

Kalofonos, Ippolytos. 2008. "Prayer is Medicine": HIV Evangelization in Central Mozambique. Paper presented to the workshop Religious Engagements with Disease Past and Present, Copenhagen, 28 April.

Klaits, Frederick. 2005. The Widow in Blue: Blood and the Morality of Remembering in Botswana. Africa 75(1):46-62.

Luedke, T. 2007. Spirit and Matter:The Materiality of Mozambican Prophet Healing. Journal of Southern African Studies 33(4):715-731.

Maxwell, D. 2000. "Catch the Cockerel Before Dawn": Pentecostalism and Politics in Postcolonial Zimbabwe. Africa 70(2):249-277.

Meyer, B., and M. Annelies, eds. 2006. Religion, Media, and the Public Sphere. Bloomington and Indianapolis: Indiana University Press.

Nattrass, Nicoli, ed. 2005. AIDS and Healing Strategies in South Africa. Social Dynamics 31(2): 1-33.

Nicolson, Ronald. 1996. God in AIDS? A Theological Enquiry. London: SCM.

Niehaus, Isak. 2009. Leprosy of a Deadlier Kind: Christian Conceptions of AIDS in the South African Lowveld. In Aids and Religious Practice in Africa, edited by Felicitas Becker and P. Wenzel Geissler. Leiden, Boston: Brill.

Nguyen, V. K. 2004. Antiretroviral Globalization, Biopolitics and Therapeutic Citizenship. In Global Assemblages: Technology, Politics and Ethics, edited by A. Ong and S. Collier. London: Blackwell. 2009.Therapeutic Evangelism: Confessional Technologies, Antiretrovirals and Biospiritual Transformation in the Fight against AIDS in West Africa. In Aids and Religious Practice in Africa, edited by Felicitas Becker and P. Wenzel Geissler. Leiden, Boston: Brill. 
Parsitau, Damaris. 2008. From Fishers of Men and Women to Fishers of Votes: Kenyan Pentecostal Clergy in the Scramble for Votes during the 2007 General Elections. Paper presented to the workshop The Kenyan Election 2007, at the University of Oxford, 17 January.

Paterson, Gillian. 2008. Stigma and Discrimination. Paper read at the workshop organized by the Collaboration on HIV and AIDS, Religion and Theology (CHART), University of KwaZulu-Natal, in Durban, 12-17 October.

Pfeiffer, James. 2004. Condoms, Social Marketing, Pentecostalism, and Structural Adjustment in Mozambique. Medical Anthropology Quarterly 18(1):77-103.

Phiri, Isabel Apawo, Beverley Haddad, and Masenya Madipoane. 2003. African Women, HIV/AIDS and Faith Communities. Pietermaritzburg: Cluster Publications.

Prince, Ruth J. 2007. Salvation and Tradition: Configurations of Faith in a Time of Death. Journal of Religion in Africa 37(1):84-115.

Ranger, Terence. 1992. Godly Medicine: The Ambiguities of Medical Mission in Southeastern Tanzania. In The Social Basis of Health and Healing in Africa, edited by Steve Feierman and John M. Janzen. Berkeley: University of California Press.

Richardson, Neville. 2006. A Call for Care: HIV/AIDS Challenges the Church. Journal of Theology for Southern Africa 125:38-50.

Sabar-Friedman, Gaia. 1996. The Power of the Familiar: Everyday Practices in the Anglican Church of Kenya (CPK). Journal of Church and State 38:377-395.

Sadgrove, Jo. 2009. "Keeping Up Appearances": Sex and Religion amongst University Students in Uganda. In Aids and Religious Practice in Africa, edited by Felicitas Becker and P. Wenzel Geissler. Leiden, Boston: Brill.

Schumaker, L., D. Jeater, and T. Luedke. 2007. Introduction: Histories of Healing: Past and Present Medical Practices in Africa and the Diaspora. Special issue, Journal of Southern African Studies 33(4):707-714.

Shorter, A., and E. Onyancha. 1998. The Church and AIDS in Africa: A Case Study: Nairobi City. Nairobi: Paulines Publications Africa.

Smith, Daniel Jordan. 2004. Youth, Sin and Sex in Nigeria: Christianity and HIV-related Beliefs and Behaviour among Rural-Urban Migrants. Culture, Health \& Sexuality 6(5):425-437.

Svensson, Jonas. "Muslims have Instructions": HIV/AIDS, Modernity and Islamic Religious Education in Kisumu, Kenya. In Aids and Religious Practice in Africa, edited by Felicitas Becker and P. Wenzel Geissler. Leiden, Boston: Brill.

Ter Haar, Gerrie, and Stephen Ellis. 2006. The Role of Religion in Development: Towards a New Relationship between Europe and Africa. European Journal of Development Research 18(3): 351-367.

Whyte, S. R., Michael Whyte, Lotte Meinert, and Betty Kyaddondo. 2006. Treating AIDS: Dilemmas of Unequal Access in Uganda. In Global Pharmaceuticals: Ethics, Markets, Practices, edited by Adriana Petryna, Andrew Lakoff, and Arthur Kleinman. Durham and London: Duke University Press.

World Council of Churches. 2005. Partnerships between Churches and People Living with HIV/AIDS Organizations. Retrieved 26 June 2009 from www.oikumene.org/fileadmin/files/wcc-main/ documents/p4/guidelines-e/pdf. 


\section{CORNELL UNIVERSITY PRESS}

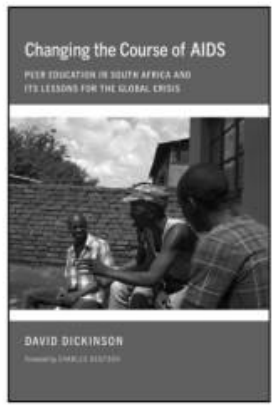

\section{Changing the Course of AIDS}

Peer Education in South Africa and Its Lessons for the Global Crisis

David Dickinson

Foreword by Charles Deutsch

"Much has been written about the AIDS pandemic in sub-Saharan Africa, where the disease has left a devastating human toll. Often miss. ing from these accounts, however, are the voices of real people living with the disease. Dickinson's powerful work fills this void by providing poignant and moving account about people living with HIV and AIDS who are doing something to combat the spread of the deadly virus in their com. munities."

\footnotetext{
-Jennifer J. Furin, Harvard Medical School

272 pages / \$39.95 cloth | An ILR Press Book The Culture and Politics of Health Care Work
}

\section{From Servants to Workers}

South African Domestic Workers and the

Democratic State

Shireen Ally

"From Servants to Workers is a readable and engaging volume containing multiple strong voices of women informants and union activists. Ally describes the measures that the post apartheid South African state has taken to professionalize and formalize domestic service."

- Michele Ruth Gamburd, Portland State University 240 pages / \$22.95 paper | AN ILR Press BooK

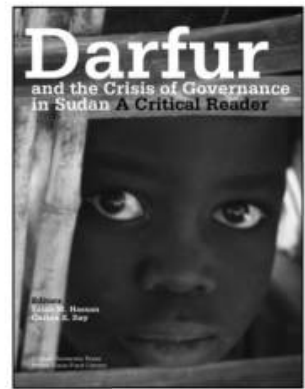

\section{Darfur and the Crisis of Governance in Sudan \\ A Critical Reader Edited by \\ Salah M. Hassan and \\ Carina E. Ray}

Foreword by Andreas Eshete "This intelligently edited col. lection of essays fills a major gap, long left void by the ab. sence of the voices of Sudanese and other continental Africans, in the genocide debate on Darfur."

- Manthia Diawara, NYU 528 pages / $\$ 39.95$ paper PUBLISHED IN COLLABORATION WITH THE Prince Claus Fund Library

\section{Bush Wives and Girl Soldiers}

Women's Lives through War and Peace in Sierra Leone

Chris Coulter

"Coulter's Bush Wives and Girl Soldiers is a groundbreaking study of female ex-combatants in Sierra Leone. Through one of the most sensi. tive ethnographies of conflict available, she explores young women's predicaments and strategies for living in a violent conflict, their renegotiation of gendered lives in postwar families and communities, and their responses to contradictions generated by international processes of disarmament, demobilization, and reintegration." - Rosalind Shaw, Tufts University 296 pages / \$24.95 paper

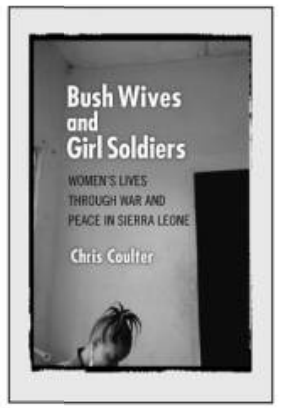

